\title{
Water quality monitoring of an agricultural watershed lake: the effectiveness of agricultural best management practices
}

\author{
R. Lizotte, S. Knight, M. Locke, W. Steinriede, \\ S. Testa \& C. Bryant \\ USDA-ARS National Sedimentation Laboratory, USA
}

\begin{abstract}
Beasley Lake is an oxbow lake located in the Lower Mississippi Alluvial Plain (the Delta), a region of extensive agricultural activity. Due to intensive row-crop agricultural practices, the 915ha watershed was sediment impaired when monitoring began in 1995 and was a candidate to assess the effectiveness of watershed-wide agricultural Best Management Practices (BMPs) on lake Water Quality (WQ). BMPs within crop fields, at field edges throughout the watershed, and enrolment of 113ha into Conservation Reserve Program (CRP) were implemented from 1997-2003 targeting reductions in sediment runoff. Bi-weekly WQ data from 1996-2009 were analyzed. WQ parameters assessed include Total Dissolved Solids (TDS), Total Suspended Solids (TSS), Filterable Orthophosphate (FOP), Total Orthophosphate (TOP), Total Nitrate Nitrogen $\left(\mathrm{NO}_{3}\right)$, Total Ammonia Nitrogen $\left(\mathrm{NH}_{3}\right)$, chlorophyll $a$, and water clarity (secchi visibility depth). Over the 14-year period, TSS, TOP, $\mathrm{NO}_{3}$, and $\mathrm{NH}_{3}$ decreased annually whereas chlorophyll $a$ and water clarity increased in conjunction with implemented BMPs. FOP appeared unaffected throughout the monitoring period. While annual improvement in WQ occurred, distinct seasonal effects were noticeable. Changes in TSS, TOP, $\mathrm{NO}_{3}, \mathrm{NH}_{3}$, and water clarity were greatest during spring and negligible in winter. Changes in TDS were observed only during summer. Reductions in spring TSS directly reduced TOP, increased chlorophyll $a$ and water clarity. Results of this study indicate clear improvement in Mississippi Delta lake WQ with watershed-wide implementation of agricultural BMPs and these improvements, manifested most strongly during spring, will promote a healthy, sustainable lake ecosystem.
\end{abstract}

Keywords: oxbow lake, conservation practices, solids, nutrients, chlorophyll a. 


\section{Introduction}

As the world's human population continues to expand, currently estimated at just below 7 billion [1], the need for agricultural products such as food and fibre will also continue to increase. Balanced against these needs is the need for ecologically sustainable freshwater resources. Freshwater lakes are utilized by humans for a variety of purposes including recreation, drinking water, and irrigation water for agriculture [2a, 3a]. Although freshwater lakes comprise $126,000 \mathrm{~km}^{3}$ world-wide, they account for only $0.009 \%$ of the total global water volume [3a] and are a valuable but finite resource.

Intensive agricultural practices such as row-crop production under conventional farming practices utilizes most available arable land. Modern agricultural practices require significant use of both fertilizers and pesticides for efficient crop cultivation and maximum crop growth and productivity [4]. In 2008, world agricultural nutrient consumption for nitrogen and phosphorus was 99.2 million tonnes and 36.6 million tonnes, respectively [4]. While beneficial and necessary, these practices may also lead to surface runoff and soil erosion during rainfall events that produce increased loads of suspended sediment, nutrients and other pollutants. Increased contamination of lakes resulting from runoff may decrease lake ecosystem services and contribute to ecologically unsustainable lake systems [5, 6]. In 2000, the US National Water Quality Inventory reported that agricultural non-point source pollution was the greatest source of water quality impacts on surveyed lakes and rivers in the USA [7]. Because of this, there was a need for a national assessment of conservation best management practices (BMPs) used in maintaining and enhancing natural resources such as lakes. In 2003, the Conservation Effects Assessment Project (CEAP) was initiated to provide a scientific basis for this assessment [8]. Beasley Lake, a historically agriculturally impacted oxbow lake located in the Lower Mississippi River Alluvial Plain, was chosen as one of 14 study watersheds included in CEAP. Reasons for this included an extensive database (8 years) already available on the understanding and contributions of multiple integrated BMPs from farm plot to watershed scales $[9,10]$.

As part of the national CEAP assessment, this study documents the effectiveness of watershed-wide agricultural best management practices (BMPs) on lake water quality. The study presents the evolution of multiple BMP implementation and integration within the Beasley Lake watershed and concomitant changes in lake surface water quality such as suspended sediment and nutrient loads during a 14-year monitoring period (1996-2009). The resulting database provides watershed-wide comprehensive assessment of the effects of multiple integrated BMPs on lake rehabilitation and sustainability.

\section{Materials and methods}

Beasley Lake watershed, located in Sunflower County, MS, USA: latitude $33^{\circ} 24^{\prime} 15^{\prime} \mathrm{N}$, longitude $90^{\circ} 40^{\prime} 05^{\prime} \mathrm{W}$, was selected as a CEAP watershed beginning in 2003 (fig. 1). Watershed drainage area is approximately 915ha and 
a lake surface area of approximately 25-30ha. Approximately 150 ha of the watershed is non-arable riparian wetland with bottomland hardwood forest and herbaceous riparian vegetation. The $722 \mathrm{ha}$ of arable land has been in row-crop production with primarily cotton (Gossypium hirsutum L.), soybeans (Glycine $\max$ [L.] Merr.), and corn (Zea mays L.), and occasionally milo (Sorghum bicolor L.) throughout the 14-year study period. During the 14-year monitoring period a total of six independent BMPs were implemented. From 1994-1996, three structural edge-of-field BMPs were implemented: (a) vegetative filter strips comprised of switchgrass (Panicum virgatum L.) or fescue (Festuca arundinacea Schreb.); and either (b) slotted board risers for water impoundment during the non-agricultural wet season; or (c) slotted inlets to impede water flow that were positioned in pipes at outlets of individual sub-drainage areas [11]. These BMPs were implemented to reduce suspended sediment loads and accompanying contaminants (e.g. phosphorus, pesticides) from entering Beasley Lake. Beginning in 2001-2002, reduced tillage management for cotton and soybeans were implemented within much of the arable portions of the watershed and from 2002-2004, 2006, and 2008-2009, reduced tillage soybeans was the primary rowcrop (52-84\%). From 2003-2004 approximately 113ha of arable land was removed from row-crop production and planted in eastern cottonwood trees (Populus deltoides Bartr. Ex. Marsh.), oak trees (Quercus sp.), and hickory trees (Carya sp.) under implementation of the Conservation Reserve Program (CRP) $[11,12]$. In 2006 approximately 4-5ha of arable land along the southern lake shoreline was removed from row-crop production and converted to vegetative buffer habitat to attract northern bobwhite quail (Colinus virginianus) (fig. 1).

Three lake sites were designated for water quality monitoring at locations one-third distance from lake inflow, at lake mid-point, and one-third distance from lake outflow (fig. 1). Water clarity was measured at each site as depth of Secchi-disc visibility according to methods described by Scheffer [13]. At each site, approximately $1 \mathrm{~L}$ of water was collected at mid-distance from shoreline and within $5 \mathrm{~cm}$ of the lake surface biweekly from January 1996 through December 2009 [12]. Water samples were chilled on wet ice $\left(4^{\circ} \mathrm{C}\right)$ and transported back to the United States Department of Agriculture-Agricultural Research Service (USDA-ARS) National Sedimentation Laboratory, Oxford, Mississippi for analyses. Measured water quality parameters included: total dissolved solids (TDS, filtered through a $45 \mu \mathrm{m}$ cellulose nitrate filter and dried at $180^{\circ} \mathrm{C}$ ), total suspended solids (TSS, dried at $180^{\circ} \mathrm{C}$ ), filterable ortho-P (FOP, filtered through a $45 \mu \mathrm{m}$ cellulose nitrate filter and analyzed using the ascorbic acid method), total ortho-P (TOP, persulfate digestion with ascorbic acid method), $\mathrm{NO}_{3}-\mathrm{N}$ (cadmium reduction method), $\mathrm{NH}_{3}-\mathrm{N}$ (phenate method), and chlorophyll $a$ (pigment extraction and spectrophotometric determination) analyzed according to Eaton et al. [14].

Data analysis was conducted using a one-way analysis of variance (ANOVA) on ranks (Kruska-Wallis test) to test for change over time of annual median values for all water quality parameters. To facilitate assessment of BMP implementation preceding a water quality response, a Dunn's multiple 


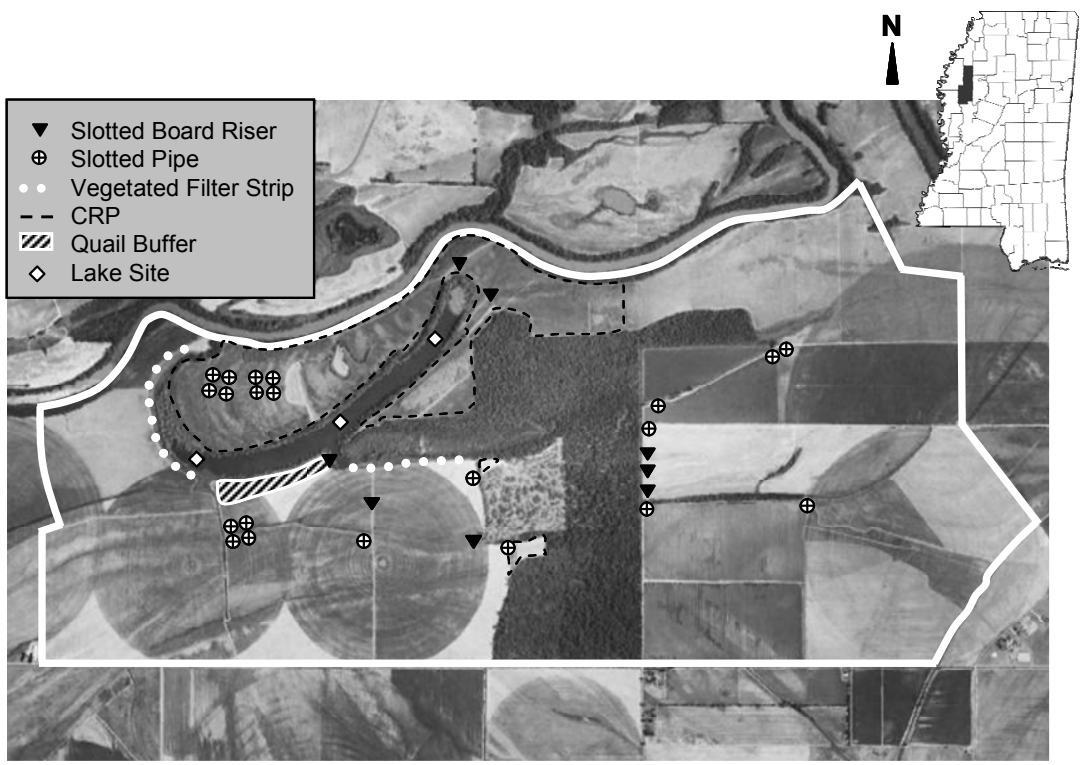

Figure 1: Map of Beasley Lake watershed depicting structural best management practices and lake monitoring sites.

BMPs initiated in 1996, 1996 (pre-BMP) versus 1997-2000; BMPs initiated in 2001, 2000 (pre-BMP) versus 2001-2002; BMPs initiated in 2003, 2002 (preBMP) versus 2003-2005; and BMPs initiated in 2006, 2005 (pre-BMP) versus 2006-2009. To further elucidate integrated effects of implementation of multiple BMPs over time, a Spearman's rank correlation analysis was completed to examine associations between changes in annual averages of each water quality parameter and implementation of six BMPs over the 14-year monitoring period. Statistical significance level for all analyses was set at $\alpha \leq 0.05$ [15].

\section{Results and discussion}

Integrated implementation of multiple conservation farm BMPs significantly improved lake-surface water quality over the course of the 14-year monitoring period. Observed average TDS from 1996-2009 ranged from about 40-100 mg/L with lowest concentrations in winter and spring and greatest concentrations in summer and fall (fig. 2) in conjunction with wetter and drier seasonal weather conditions [12]. TDS concentrations were not significantly affected by BMPs in place by 1996 (edge-of-field), but were significantly reduced by $19-25 \%$ after implementation of reduced tillage in 2001 (table 1). Neither BMPs in place by 2003 (CRP) or 2006 (quail buffer) were significantly or consistently effective in changing TDS. Average TSS concentrations ranged from about 10-400 mg/L during 1996-2009 with distinct seasonal differences (fig. 2). Greatest 

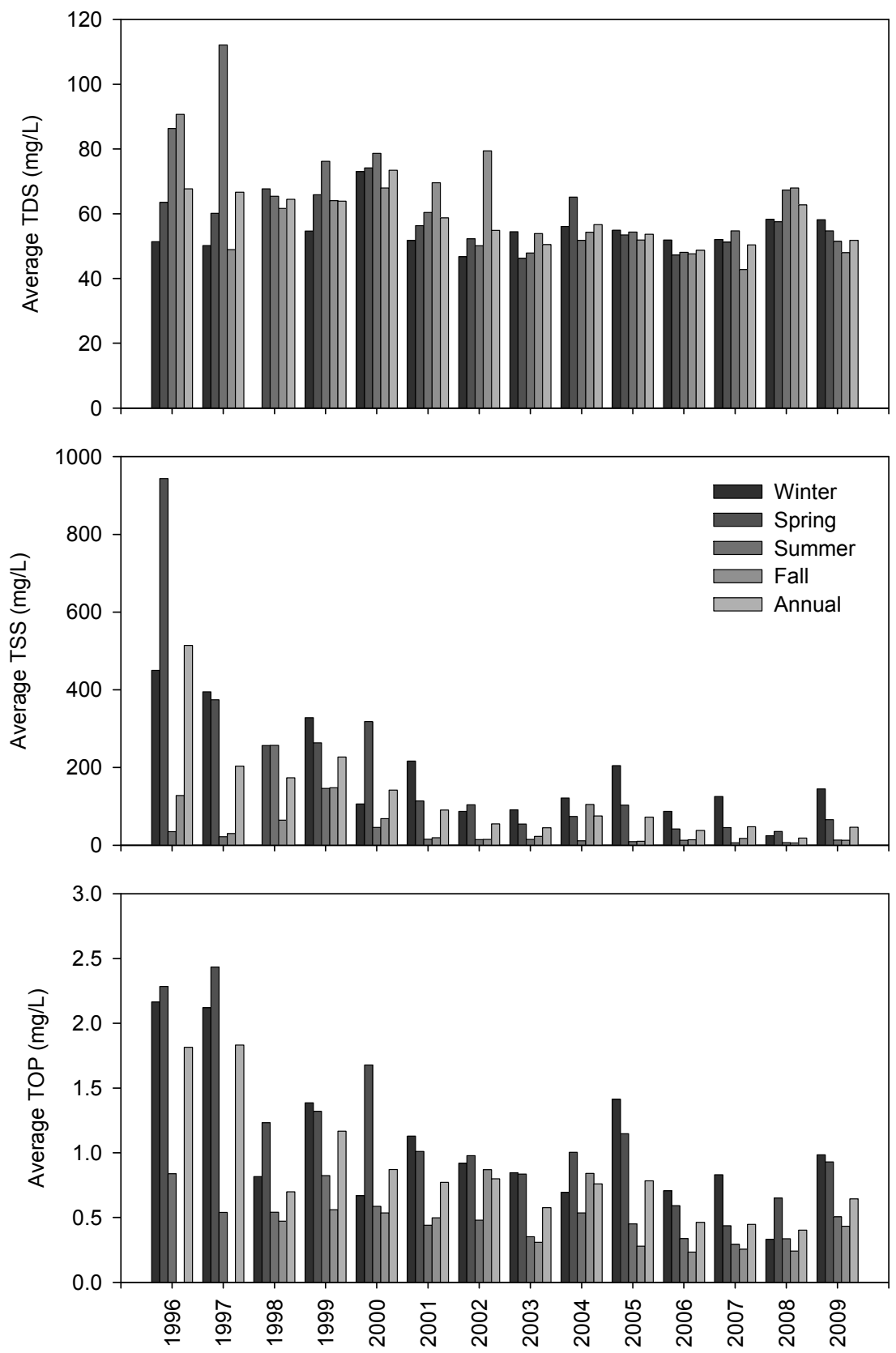

Figure 2: Average seasonal and annual TDS, TSS, and TOP in Beasley Lake during 1996-2009. 
concentrations occurred in winter and spring and lowest concentrations occurred in summer and fall in close association with annual rainfall patterns [12]. TSS concentrations significantly decreased $59-72 \%$ after placement of edge-of-field BMPs in 1996 and further decreased another 37-61\% after reduced tillage in 2001 (table 1). TSS was unaffected by CRP but exhibited another $50 \%$ decrease in 2008 after implementation of quail buffer in 2006. Average concentrations of TOP from 1996-2009 ranged from about 0.3-2.2 mg/L in Beasley Lake (fig. 2). Greatest concentrations occurred in winter and spring and lowest concentrations occurred in summer and fall in association with TSS [16]. Concentrations of TOP significantly decreased by $36-62 \%$ after placement of edge-of-field BMPs in 1996, but TOP was not consistently affected by implementation of reduced tillage in 2001 or CRP in 2003 (table 1). TOP further decreased by $41-49 \%$ after implementation of quail buffer in 2006.

Table 1: Years when annual median values of measured water quality parameters significantly $(P \leq 0.05)$ decreased $(\downarrow)$ or increased $(\uparrow)$ versus control years (NS, not significant).

\begin{tabular}{|l|c|c|c|c|}
\hline \multirow{2}{*}{ Parameter } & \multicolumn{4}{|c|}{ Reference (pre-BMP) Years } \\
\cline { 2 - 5 } & 1996 & 2000 & 2002 & 2005 \\
\hline TDS & NS & $\downarrow 2001-2002$ & NS & $\downarrow 2006$, \\
& & & & NS \\
\hline TSS & $\downarrow 1998,2000$ & $\downarrow 2001-2002$ & $\downarrow 2008$ \\
\hline TOP & $\downarrow 1998-2000$ & NS & $\downarrow 2003$ & $\downarrow 2006-2008$ \\
\hline FOP & $\downarrow 1998$ & $\uparrow 2002$ & $\downarrow 2003-2005$ & $\uparrow 2009$ \\
\hline $\mathrm{NO}_{3}$-N & $\downarrow 1998-2000$ & $\downarrow 2002$ & NS & $\downarrow 2008$ \\
\hline $\mathrm{NH}_{3}$-N & NS & $\downarrow 2001-2002$ & $\downarrow 2003-2005$ & $\uparrow 2006-2009$ \\
\hline Chlorophyll $a$ & $\uparrow 1997-2000$ & NS & NS & $\uparrow 2008$ \\
\hline Water Clarity & $\downarrow 1999$ & $\uparrow 2001-2002$ & $\uparrow 2003-2005$ & $\uparrow 2008$ \\
\hline
\end{tabular}

For soluble nutrients, observed average FOP concentrations ranged from about $0.05-0.3 \mathrm{mg} / \mathrm{L}$ in Beasley Lake from 1996-2009 with no clear seasonal patterns (fig. 3). FOP concentrations were not consistently affected by edge-offield BMPs installed in 1996, reduced tillage in 2001 or quail buffer in 2006. FOP concentrations were consistently significantly reduced by $34-52 \%$, however, after implementation of CRP in 2003 (table 1). Average $\mathrm{NO}_{3}-\mathrm{N}$ concentrations ranged from about 0.04-1.2 mg/L from 1996-2009. Greatest $\mathrm{NO}_{3}$ $\mathrm{N}$ concentrations occurred in winter and spring and lowest concentrations occurred in summer (fig. 3). Similar to TOP, $\mathrm{NO}_{3}-\mathrm{N}$ significantly decreased 16$73 \%$ after placement of edge-of-field BMPs in 1996 but was less affected by reduced tillage, CRP and quail buffer (table 1). Average $\mathrm{NH}_{3}-\mathrm{N}$ concentrations ranged from about $<0.01-0.38 \mathrm{mg} / \mathrm{L}$ from 1996-2009 with greatest average concentrations occurring in winter and spring and lowest occurring in fall (fig. 3). $\mathrm{NH}_{3}-\mathrm{N}$ concentrations were not significantly affected by edge-of-field BMPs in place by 1996 . But $\mathrm{NH}_{3}-\mathrm{N}$ concentrations were significantly reduced by $30-$ $74 \%$ after implementation of reduced tillage in 2001 and further reduced by 70 - 

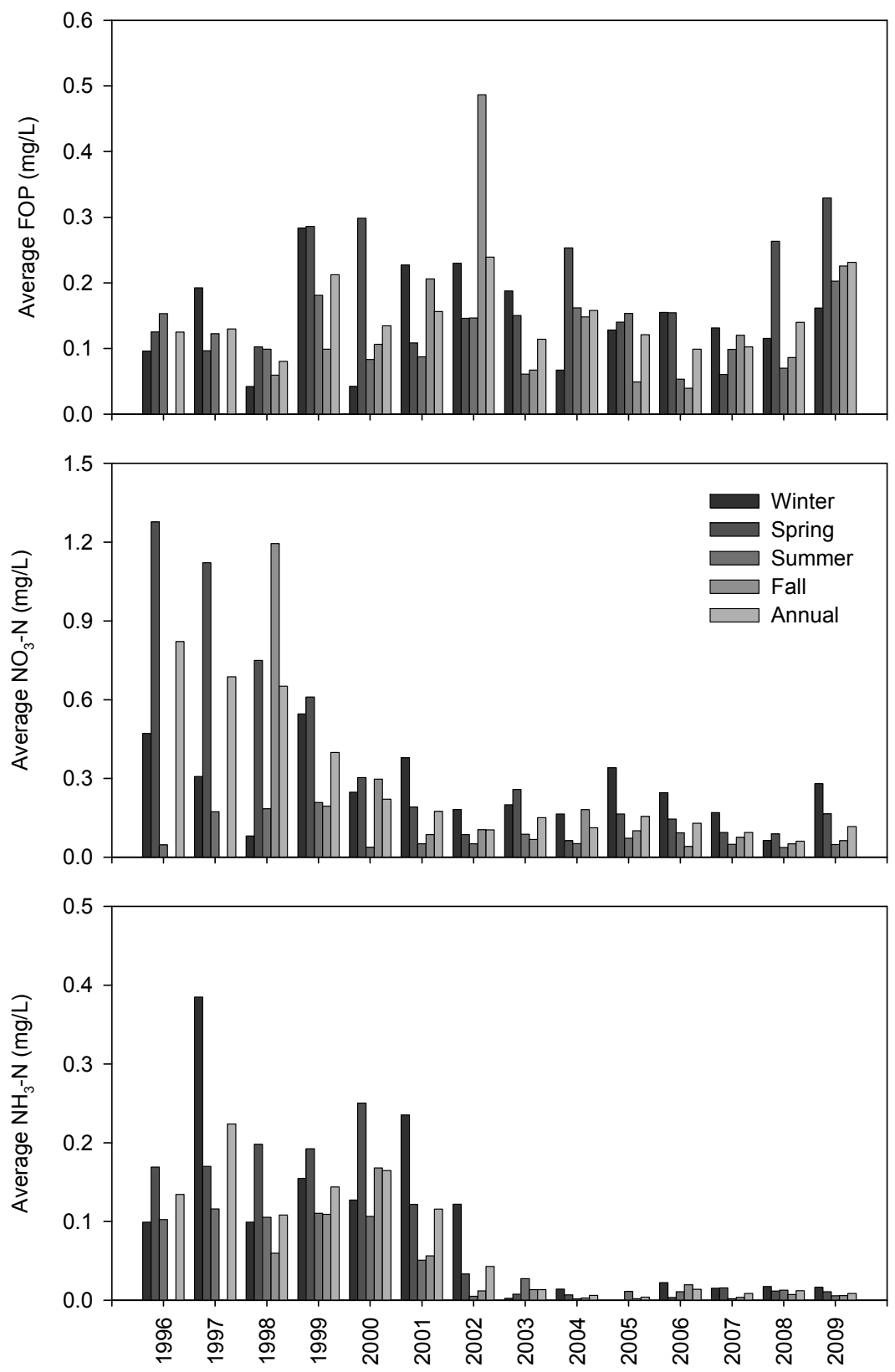

Figure 3: Average seasonal and annual FOP, $\mathrm{NO}_{3}-\mathrm{N}$, and $\mathrm{NH}_{3}-\mathrm{N}$ in Beasley Lake during 1996-2009. 
91\% after implementation of $\mathrm{CRP}$ in 2003 (table 1). $\mathrm{NH}_{3}-\mathrm{N}$ concentrations statistically significantly increased after quail buffer BMP implemented in 2006, but these increases were modest from $<0.01 \mathrm{mg} / \mathrm{L}$ (2005) to approximately 0.01 $\mathrm{mg} / \mathrm{L}$ (2006).

Beasley Lake surface water chlorophyll $a$ concentrations were used as an indirect measure of total algal biomass [14, 17]. Average chlorophyll $a$ concentrations ranged widely from about 3-65 $\mu \mathrm{g} / \mathrm{L}$ during 1996-2009 with distinct seasonal differences (fig. 4). Greatest concentrations occurred in spring and summer and lowest concentrations occurred in fall and winter in association with growing seasons. In conjunction with reduction in TSS, chlorophyll $a$ concentrations significantly increased by $439-838 \%$ after implementation of edge-of-field BMPs in 1996. Thereafter, chlorophyll $a$ was not significantly affected by implementation of reduced tillage in 2001 or CRP in 2003 (table 1).
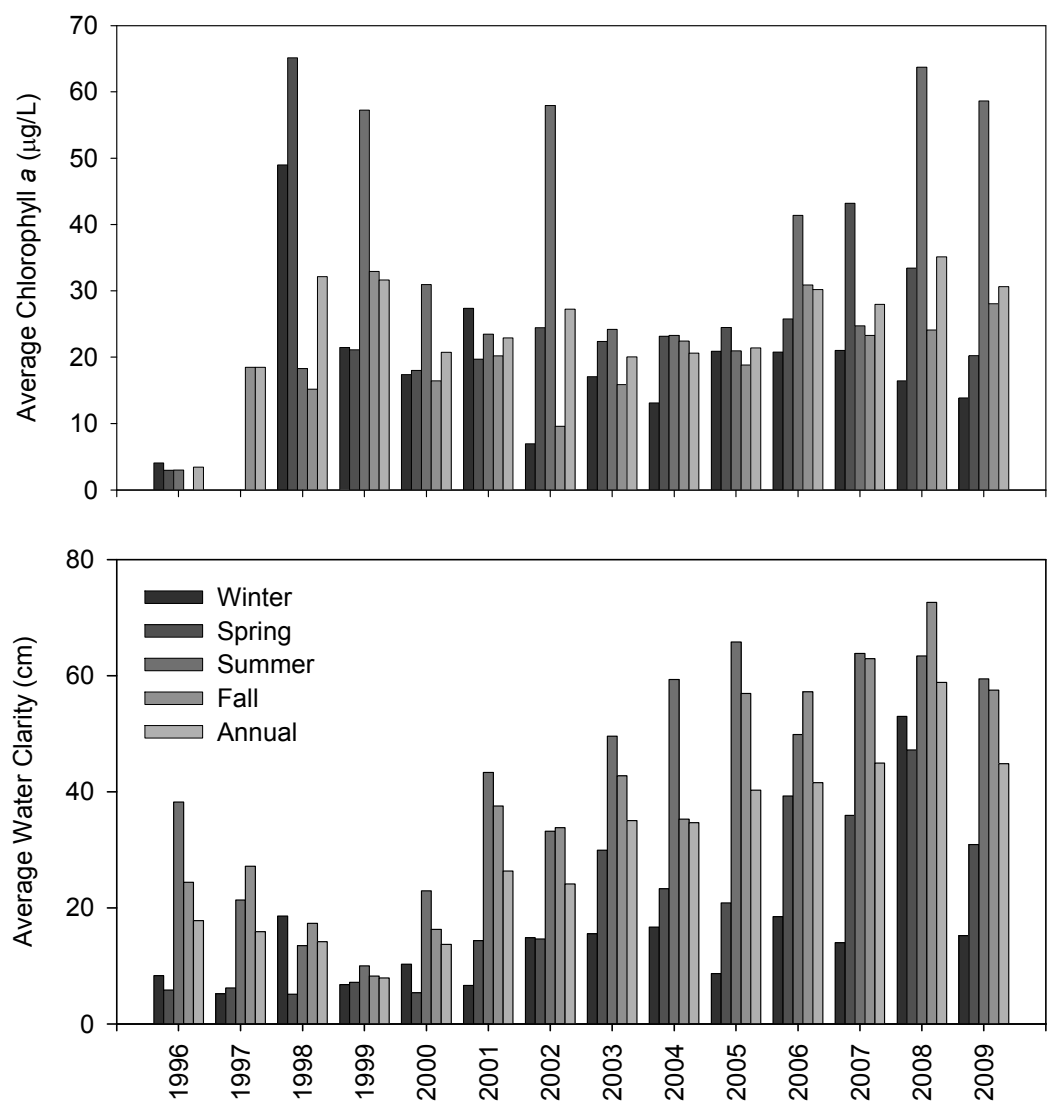

Figure 4: Average seasonal and annual chlorophyll $a$ and water clarity (measured as Secchi visibility depth) in Beasley Lake during 19962009. 
Another significant but modest increase (76\%) in chlorophyll $a$ was observed in 2008 after implementation of quail buffer in 2006. Average depth of water clarity in Beasley Lake also ranged widely from about $5-73 \mathrm{~cm}$ during 19962009 (fig. 4). Greatest water clarity occurred in summer and fall and lowest clarity occurred in winter and spring, inversely proportional to lake water TSS concentrations and in conjunction with annual rainfall patterns [12]. Water clarity was not consistently affected by edge-of-field BMPs in place by 1996, but a significant decrease (55\%) in water clarity was observed in 1999 (table 1). In contrast, water clarity increased $71-86 \%$ after implementation of reduced tillage in 2001 and further increased by 46-67\% after implementation of CRP in 2003 (table 1). Water clarity statistically significantly increased again (48\%) in 2008 after quail buffer BMP implemented in 2006.

Over the course of the 14-year monitoring period, the watershed has had a total of six independent conservation BMPs implemented. Multiple water quality parameters of solids, nutrients and water clarity responded to two or more of these and, in several instances, indicated a cumulative effect. Assessment of the integrated effects of these BMPs on lake water quality showed most of these variables to be correlated with implementation of multiple BMPs over time (table 2). Average TDS and TOP concentrations were significantly negatively correlated with multiple BMPs over time during every season except winter. Highest negative correlation coefficients occurred for annual average TDS and spring TOP, respectively (table 2). Average TSS and $\mathrm{NH}_{3}-\mathrm{N}$ concentrations were significantly negatively correlated with multiple BMPs through every season with highest negative correlation coefficients observed in spring. Average $\mathrm{NO}_{3}$ $\mathrm{N}$ concentrations were significantly negatively correlated with multiple BMPs during spring, fall and annual conditions. Average depth of water clarity was significantly positively correlated with multiple BMPs through every season with highest positive correlation coefficients observed in spring. Only two parameters, FOP and chlorophyll $a$, were not significantly correlated with multiple BMPs over time (table 2).

Table 2: $\quad$ Spearman's rank correlation coefficients $(r)$ showing associations between average seasonal and annual values of measured water quality parameters and implementation of six BMPs over the 14year monitoring period (bold values are significant $r$-values; $P \leq$ $0.05)$.

\begin{tabular}{|l|c|c|c|c|c|}
\hline Parameter & Winter & Spring & Summer & Fall & Annual \\
\hline TDS & 0.310 & $\mathbf{- 0 . 6 9 3}$ & $\mathbf{- 0 . 6 5 7}$ & $\mathbf{- 0 . 5 7 2}$ & $\mathbf{- 0 . 8 3 0}$ \\
\hline TSS & $\mathbf{- 0 . 5 5 8}$ & $\mathbf{- 0 . 9 4 5}$ & $\mathbf{- 0 . 8 8 5}$ & $\mathbf{- 0 . 7 5 7}$ & $\mathbf{- 0 . 9 0 6}$ \\
\hline TOP & -0.400 & $\mathbf{- 0 . 9 1 0}$ & $\mathbf{- 0 . 8 4 0}$ & $\mathbf{- 0 . 7 1 7}$ & $\mathbf{- 0 . 8 4 6}$ \\
\hline FOP & 0.021 & 0.194 & -0.208 & -0.062 & -0.055 \\
\hline $\mathrm{NO}_{3}-\mathrm{N}$ & -0.428 & $\mathbf{- 0 . 7 3 7}$ & -0.300 & $\mathbf{- 0 . 8 8 7}$ & $\mathbf{- 0 . 8 4 0}$ \\
\hline $\mathrm{NH}_{3}-\mathrm{N}$ & $\mathbf{- 0 . 6 7 3}$ & $\mathbf{- 0 . 8 0 1}$ & $\mathbf{- 0 . 7 6 6}$ & $\mathbf{- 0 . 6 7 7}$ & $\mathbf{- 0 . 8 0 1}$ \\
\hline Chlorophyll $a$ & -0.145 & -0.441 & 0.450 & 0.490 & 0.348 \\
\hline Water Clarity & $\mathbf{0 . 5 3 8}$ & $\mathbf{0 . 9 6 1}$ & $\mathbf{0 . 8 6 5}$ & $\mathbf{0 . 9 4 9}$ & $\mathbf{0 . 9 6 1}$ \\
\hline
\end{tabular}


Large-scale (watershed) longer-term ( $>5$ years) studies such as the current study are essential to improved understanding of how agriculturally impacted lakes can be rehabilitated and sustained using multiple integrated conservation BMPs. Several studies are available quantifying mitigation of agricultural runoff using a specific type of BMP such as vegetative filter strips [18], reduced tillage practices [16] and conservation reserve practices [12] at smaller, field plot scales. Fewer studies have attempted to assess these BMPs at a watershed scale $[9,11$, 19]. The current study observed continuing improved lake surface water conditions with cumulative implementation of a variety of BMPs from structural localized edge-of-field practices in 1996 and 2006, to watershed-wide cultural practices such as reduced tillage in 2001 and watershed-wide structural practices such as the conservation reserve program in 2003. Underlying all these BMPs has been the goal to reduce pollutant loadings into the lake, beginning with suspended sediment. Suspended sediments derived from erosion of loose soil during runoff events on agricultural land is the primary source of ecological degradation in oxbow lakes in south eastern USA [20]. Suspended sediments, themselves, can have direct effects on the integrity of lake ecosystems by limiting water clarity, primary productivity and decreasing animal diversity [2022]. Sediments can also transport nutrients such as soil-bound phosphorus [16, 23] causing eutrophic and hypertrophic conditions within the lake after sediments settle from the water column. As a result, reductions in TSS concentrations within Beasley Lake surface water due to integrated implementation of multiple BMPs within the watershed likely induced a cascade of concomitant changes such as decreased nutrients, increased primary productivity (algal biomass) and increased water clarity leading to lake rehabilitation and sustainability.

\section{Conclusions}

Results of the current study provide a greater understanding of the role of agricultural BMPs in improving water quality. Watershed-wide implementation of multiple agricultural BMPs over the course of the 14-year study period reduced sediments and nutrients while increasing water clarity, especially during spring and summer. Beasley Lake TSS and TOP decreased annually after implementation of nearly every BMP. Beasley Lake nitrogen was reduced and water clarity increased after implementation of reduced tillage (2001-2002) followed by implementation of CRP (2003-2004) BMPs and continued thereafter. These results have far-reaching implications for aiding researchers and lake managers in attaining and maintaining a healthy, sustainable lake ecosystem.

\section{References}

[1] United States Census Bureau, http://www.census.gov/main/www/ popclock.html 
[2] Cole, G.A., Textbook of Limnology, $3^{\text {rd }}$ ed., Waveland Press, Inc.: Prospect Heights, pp.401, 1988.

[3] Wetzel, R.G., Limnology: Lake and River Ecosystems, $3^{\text {rd }}$ ed., Elsevier Academic Press: San Diego, pp.1006, 2001.

[4] FAO, http://faostat.fao.org/site/575/default.aspx\#ancor

[5] Cooper, C.M., Shields, F.D., Testa, S. and Knight, S.S., Sediment retention and water quality enhancement in disturbed watersheds. International Journal of Sediment Research, 15(1), pp.121-134, 2000.

[6] Carpenter, S.R. and Lathrop, R.C., Lake restoration: capabilities and needs. Hydrobiologia, 395/396, pp.19-28, 1999.

[7] United States Environmental Protection Agency (USEPA), Protecting water quality from agricultural runoff. Fact Sheet, EPA 841-F-05-001, March 2005.

[8] Karlen, D.L., A new paradigm for natural resources research: the Conservation Effects Assessment Project. Journal of Soil and Water Conservation, 63(6), pp.220A, 2008.

[9] Cullum, R.F., Knight, S.S., Cooper, C.M. and Smith, S., Combined effects of best management practices on water quality in oxbow lakes from agricultural watersheds. Soil \& Tillage Research, 90, pp.212-221, 2006.

[10] Zablotowicz, R.M., Locke, M.A., Krutz, L.J., Lerch, R.N., Lizotte, R.E., Knight, S.S., Gordon, R.E. \& Steinriede, R.W., Influence of watershed system management on herbicide concentrations in Mississippi Delta oxbow lakes. Science of the Total Environment, 370, pp.552-560, 2006.

[11] Locke, M.A., Knight, S.S., Smith, S., Cullum, R.F., Zablotowicz, R.M., Yuan, Y. and Bingner, R.L., Environmental quality research in the Beasley Lake watershed, 1995-2007: succession from conventional to conservation practices. Journal of Soil and Water Conservation, 63(6), pp.430-442, 2008.

[12] Cullum, R.F., Locke, M.A. and Knight, S.S., Effects of conservation reserve program on runoff and lake water quality in an oxbow lake watershed. Journal of International Environmental Application \& Science, 5(3), pp. 318-328,2010.

[13] Scheffer, M., Ecology of Shallow Lakes, Kluwer Academic Publications: Boston, pp.357, 2004.

[14] Eaton, A.D., Clesceri, L.S., Rice, E.W. and Greenburg, A.E., Standard Methods for the Examination of Water and Wastewater, $21^{\text {st }} \mathrm{ed}$., American Public Health Association, American Water Works Association, Water Environment Federation, Washington DC, pp.1320, 2005.

[15] Steel, R.G.D., Torrie, J.H. and Dickey, D.A., Principles and Procedures of Statistics: a Biometrical Approach, $3^{\text {rd }}$ ed., McGraw-Hill, New York, pp.667, 1997.

[16] Schreiber, J.D., Rebich, R.A. and Cooper C.M., Dynamics of diffuse pollution from US southern watersheds. Water Research, 35(10), pp.25342542, 2001.

[17] Bellinger, E.G. and Sigee, D.C., Freshwater Algae: Identification and Use as Bioindicators, Wiley-Blackwell, West Sussex, pp.271, 2010. 
[18] Dosskey, M.G., Toward quantifying water pollution abatement in response to installing buffers on crop land. Environmental Management, 28(5), pp.577-598, 2001.

[19] Yuan, Y., Locke, M.A. and Bingner, R.L., Annualized agricultural nonpoint source model application for Mississippi Delta Beasley Lake watershed conservation practices assessment. Journal of Soil and Water Conservation, 63(6), pp.542-551, 2008.

[20] Cooper, C.M., Biological effects of agriculturally derived surface water pollutants on aquatic systems - a review. Journal of Environmental Quality, 22(3), pp.402-408, 1993.

[21] Jones, J.R., Obrecht, D.V., Perkins, B.D., Knowlton, M.F., Thorpe, A.P., Watanabe, S. and Bacon, R.R., Nutrients, seston, and transparency of Missouri reservoirs and oxbow lakes: an analysis of regional limnology. Lake and Reservoir Management, 24, pp.155-180, 2008.

[22] Izagirre, O., Serra, A., Guasch, H. and Elosegi, A., Effects of sediment deposition on periphytic biomass, photosynthetic activity and algal community structure. Science of the Total Environment, 407, pp.5694-5700, 2009.

[23] Yuan, Y., Locke, M.A. and Gaston, L.A., Tillage effects on soil properties and spatial variability in two Mississippi Delta watersheds. Soil Science, 174(7), pp.385-394, 2009. 